Sains Malaysiana 51(1)(2022): 83-94

http://doi.org/10.17576/jsm-2022-5101-07

\title{
Rice Yields and Soil Nutrients Response to Liming Method and Dosages in Field Cultivation
}

(Hasil Padi dan Gerak Balas Nutrien Tanah terhadap Kaedah Pengapuran dan Dos dalam Penanaman Ladang)

\author{
ZHOU JIANG-MING*
}

\section{ABSTRACT}

It is important to develop a new convenient and environmentally-friendly technology of liming for sustainable rice production on acidic soil area. Thus, an experiment was conducted to evaluate the effect of application methods and rate of lime on soil properties and rice yield. The results showed that a similar ameliorating effect on agricultural acidic soil were found between massive quicklime and powered hydrated lime. Interestingly, optimized application rate of lime significantly increases rice yield, while over-liming leads to an adverse effect to the rice production. The changes of soil nutrients affected by liming rates were related to organic matter content and soil texture, with elevated mineralization of organic matter were found in organic and sandy soil. Conclusively, massive quicklime method has been found to be optimal for rice cultivation on acidic soil conditions with rates of 1500-2250 kg/ha for clay soil and 2250-3000 kg/ha for sandy soil, respectively.

Keywords: Acidic soil; liming technique; rice growth

\section{ABSTRAK}

Pembangunan teknologi pengapuran yang mudah dan mesra alam amat penting untuk pengeluaran padi yang mampan di kawasan tanah berasid. Oleh itu, satu uji kaji telah dijalankan untuk menilai kesan kaedah aplikasi dan kadar kapur terhadap sifat tanah dan hasil padi. Keputusan menunjukkan bahawa kesan pembaikan yang sama pada tanah pertanian berasid didapati antara kapur tohor masif dan kapur tawar. Menariknya, kadar penggunaan kapur yang dioptimumkan telah meningkatkan hasil padi dengan ketara, manakala penggunaan kapur yang berlebihan membawa kepada kesan buruk terhadap pengeluaran padi. Perubahan nutrien tanah yang dipengaruhi oleh kadar pengapuran adalah berkaitan dengan kandungan bahan organik, tekstur tanah serta mineralisasi bahan organik yang tinggi ditemui dalam tanah organik dan berpasir. Secara kesimpulannya, kaedah kapur tohor masif memberikan hasil optimum bagi penanaman padi untuk tanah berasid dengan kadar masing-masing 1500-2250 kg/ha untuk tanah liat dan 2250-3000 $\mathrm{kg} / \mathrm{ha}$ untuk tanah berpasir.

Kata kunci: Tanah berasid; teknik pengapuran; tumbesaran padi

\section{INTRODUCTION}

Soil acidification is well known as being one of the most yield-limiting factors with serious constraints to food production. Particularly, more than $50 \%$ of the world's arable land has been acidified by agricultural intensification, mainly via monoculture farming and excessive use of synthetic fertilizers (Li et al. 2018). The crops grown on these acidic soils were inhibited in growth by one or more factors such as toxicity of $\mathrm{Al}, \mathrm{Mn}$, or Fe; deficiencies of nutrients; enhanced incidence of root diseases or reduced breakdown rates of organic matter (OM) (Arshad et al. 2012; Kunito et al. 2016). Liming, a common and most effective managerial practice to ameliorate soil acidity and consequentially to improve crop production, have been used in agriculture for centuries. It has been characterized by raising soil $\mathrm{pH}$ and alleviating Al toxicity (Álvarez et al. 2009; Wijanarko \& Taufiq 2016), elevating the $\mathrm{N}$ or $\mathrm{P}$ fertilizers recovery (Bailey 1995; Tucher et al. 2018), controlling crop diseases and pests (Gatch \& Toit 2017), and consequently enhancing the yield of various crops (Karaivazoglou et al. 2007; Pagani \& Mallarino 2015; Shamshuddin et al. 2016; Tang et al. 2003). Lime is usually applied as calcium carbonate (lime), calcium/magnesium carbonate (dolomitic lime), calcium oxide (burned lime), or calcium hydroxide (hydrated lime) (Gatch \& Toit 2017; Paradelo et al. 2015), while the optimum material to effectively neutralize soil $\mathrm{pH}$ is calcium hydroxide (Li et al. 2018). However, application 
of calcium hydroxide is both time-consuming and laborwasting under field conditions, and the occurrence of the powder dust during liming will pollute air environment as well as easily cause harm to operators' skin, especially eye cornea. Therefore, from the practical point of view, it is important to select the best environmental-friendly liming method with optimum dosage to increase rice production on acidic soil.

The principal aim of this work was to estimate the effect of two liming methods on rice growth and to quantify the optimum dosages in paddy field via two field experiments. The objectives of this study include: investigating the soil $\mathrm{pH}$ and rice yields under different lime application method; assessing the relationship between rice yields and lime dosages to determine an optimum liming dosage favoring rice growth on acidic soils; estimating the impact of different dosages of lime on $\mathrm{OM}$, total nitrogen (TN), and available phosphorus (avai-P) in soils under field conditions.

\section{Materials AND Methods}

\section{FIELD SITES}

The study areas are situated in Quzhou, Zhejiang Province, a major crop production region in southern China. The climate is of subtropical monsoon type, with an annual average rainfall of approximately $1760 \mathrm{~mm}$, of which $60 \%$ falls during monsoon season (April-June). Two series of field experiments were performed: a liming method experiment at the Gaojia town (GT), Qujiang city; and the liming dosage experiments represented by two sites in Jiangshan city, one at Hecun town (HT) with a soil texture of clay loam and the other at Qinghu town (QT) with a sandy loam. The detailed characteristics of paddy soils $(0-15 \mathrm{~cm}$ topsoil) analyzed before the experiments are provided in Table 1.

TABLE 1. Soil characteristics before the establishment of the experiments

\begin{tabular}{|c|c|c|c|c|}
\hline Soil & Unit & GT & HT & QT \\
\hline Sand (>2 mm) & $\%$ & 23.1 & 17.6 & 30.2 \\
\hline Silt $(0.05-2 \mathrm{~mm})$ & $\%$ & 31.3 & 25.2 & 30.1 \\
\hline Silt $(0.002-0.05 \mathrm{~mm})$ & $\%$ & 28.7 & 34.9 & 21.8 \\
\hline Clay $(<0.002 \mathrm{~mm})$ & $\%$ & 16.9 & 22.3 & 17.9 \\
\hline $\mathrm{pH}$ & & 5.98 & 5.02 & 5.12 \\
\hline OM & $\mathrm{g} / \mathrm{kg}$ & 33.3 & 16.1 & 37.2 \\
\hline $\mathrm{TN}$ & $\mathrm{g} / \mathrm{kg}$ & 1.71 & 1.15 & 2.03 \\
\hline $\mathrm{TP}$ & $\mathrm{g} / \mathrm{kg}$ & 0.546 & 0.705 & 0.552 \\
\hline TK & $\mathrm{g} / \mathrm{kg}$ & 21.15 & 11.86 & 40.28 \\
\hline Avai-N & $\mathrm{mg} / \mathrm{kg}$ & 116.8 & 94.6 & 149.9 \\
\hline Avai-P & $\mathrm{mg} / \mathrm{kg}$ & 10.1 & 97 & 11.8 \\
\hline Avai-K & $\mathrm{mg} / \mathrm{kg}$ & 102 & 75 & 231 \\
\hline
\end{tabular}

OM-Organic matter, TN-Total nitrogen, TP- Total phosphorus, TK- Total potassium, Avai-N-Available nitrogen, Avai-P-Available phosphorus, Avai-K- 


\section{EXPERIMENTAL DESIGN}

A single-crop rice of Zhongsu 143 was used as experiment material at GT. The early rice variety of Jinzao 47 for HT and Zhongzao 39 for QT, respectively, while late rice variety of Tongyou 1540 was cultivated at both sites. Sources of chemical fertilizers (N, P, K) used for this study were compound fertilizer $\left(\mathrm{N} 15 \%, \mathrm{P}_{2} \mathrm{O}_{5} 15 \%\right.$, $\left.\mathrm{K}_{2} \mathrm{O} 15 \%\right)$, urea ( $\left.46 \%\right)$, triple superphosphate $\left(\mathrm{P}_{2} \mathrm{O}_{5}\right.$ $12 \%)$ and potassium chloride $\left(\mathrm{K}_{2} \mathrm{O} 60 \%\right)$, respectively.

The experiment at GT began in April 2019 as a randomized complete block design replicated three times. A recommended lime rate of $2250 \mathrm{~kg} / \mathrm{ha}$ was applied to two plots $(3 \mathrm{~m} \times 22 \mathrm{~m})$ under flooded $(5-7 \mathrm{~cm})$ conditions, using massive quicklime (TM) or powdered hydrated lime (TP) as shown in Figure 1. The control plots received no lime. The liming material tested in this study was burned lime of different size and irregular mass shape purchased from a local quicklime mill $(\mathrm{CaO}$, about $93 \%$ ). It would be broken down into smaller pieces by hammer as presenting few large pieces in TM with weight more than $0.25 \mathrm{~kg}$. Additionally, the powdered hydrated lime was made from reaction between quicklime and water by spraying water to massive lime. Lime was mixed manually with paddy soil to a depth of about 15 $\mathrm{cm}$ using iron rake one day after application on April 2. Rice was transplanted on April 3 and harvested on July 19 of the same year.

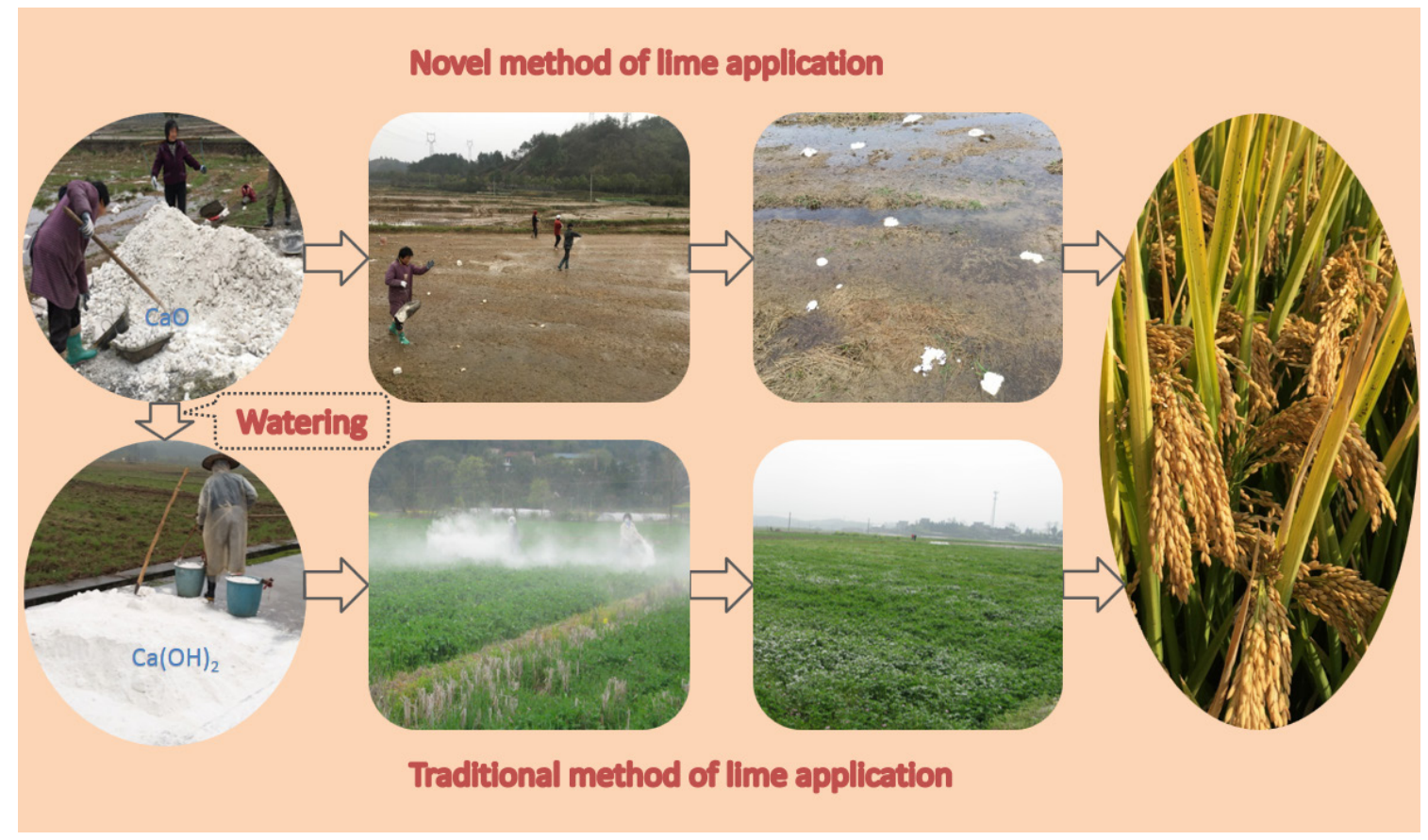

FIGURE 1. The new liming technique and traditional liming technique. TM, Massive quicklime (above); TP, Powdered hydrated lime (below)

The experiment at HT and QT began in April 2019 with six treatments in triplicates. Application rates of lime were $0,750,1500,2250,3000$, and $3750 \mathrm{~kg} / \mathrm{ha}$ in both experiments and were referred as $\mathrm{T} 0, \mathrm{~T} 1, \mathrm{~T} 2, \mathrm{~T} 3, \mathrm{~T} 4$, and $\mathrm{T} 5$, respectively. The experimental plot was randomly designed with an area of $35 \mathrm{~m}^{2}(7 \mathrm{~m} \times 5 \mathrm{~m})$. Massive lime (quicklime) was applied and mixed into the soil one day before rice transplanting. Early rice was transplanted on
14-20 April and harvested on 16-22 July, subsequent late rice was transplanted on 20-23 June and harvested on 1113 November, respectively.

Standard fertilizers (N, 135-210 kg/ha; P, 75-120 $\mathrm{kg} / \mathrm{ha}$; and $\mathrm{K}, 90-135 \mathrm{~kg} / \mathrm{ha}$ ) with twice applications were applied according to the dose of general regional recommendations at before and 4-7 days after rice transplant. Irrigation water, weeds, insects and diseases were controlled uniformly as required to avoid yield losses. 


\section{SOIL SAMPLING AND CHEMICAL ANALYSIS}

During the experimental period at GT, the soil samples were taken $(0-15 \mathrm{~cm})$ at the end of $1,3,7,30$, and 105 (rice harvest) days of lime application. Eight samples were collected every time from eight regions of fixed position uniformly in each plot, and each sample was composed from five subsamples. While, for the experiments performed at HT and QT, soils were sampled at the end of 1, 7, 30, 90 (early rice harvest) and 205 (late rice harvest) days of lime application. The grain yield of each plot was weighted after rice harvest in all experiments.

Soil samples were air-dried, ground, passed through a $2-\mathrm{mm}$ sieve following the measurement of texture in a subsample with a laser particle size analyzer (Mastersizer 3000). Soil pH was determined in a 1:2.5 (soil:water) suspension. OM was measured using potassium dichromate titration oxidation method (Mavi et al. 2018). Total nitrogen (TN) was analyzed by employing the Kjeldahl procedure, and available-N obtained by $2 \% \mathrm{H}_{3} \mathrm{BO}_{3}$ titration after reducing the nitrate into ammonical nitrogen using a reductive of $\mathrm{FeSO}_{4}$. Total phosphorus and total potassium content of soil samples were determined by the molybdenum blue-ascorbic acid method and flame photometer method after alkaline fusion $\left(\mathrm{Na}(\mathrm{OH})_{2}\right)$ at a temperature of 750 ${ }^{\circ} \mathrm{C}$ in nickel crucible, while extraction of soils with 0.025 $\mathrm{M}$ hydrochloric acid $+0.03 \mathrm{M}$ ammonium fluoride for
available-P and with $1 \mathrm{M} \mathrm{CH}_{3} \mathrm{COONH}_{4}(\mathrm{pH}=7.0)$ for available-K were analyzed using same way of TK and $\mathrm{TP}$, respectively.

\section{STATISTICAL ANALYSIS}

A one-way ANOVA was carried out to compare the means of the all the investigated factors in different treatments during different periods. When significant F-values were detected, the difference between individual means were tested using the least significant difference (LSD) test. All analyses used the statistical software DPS v 9.5.

\section{RESULTS}

\section{THE DYNAMICS OF SOIL PH AFFECTED BY APPLICATION METHOD AND RATES OF LIME}

Regardless of liming method and lime rate in three tests, soil $\mathrm{pH}$ increased with lime application against the control (Figures $2 \& 3$ ). A similar tendency in all treatments were obtained which showed a quickly rose within a week after lime application and thereafter decreased gradually at the late stage. Among two application method of lime materials (Figure 2), the increase of soil $\mathrm{pH}$ had a similar effect with an exception at 7 days after lime application, where soil $\mathrm{pH}$ in TM treatment $(7.52 \pm 1.1647)$ was significantly higher than in TP treatment $(6.65 \pm 0.7883)$. Compared to the control, a significant elevation in soil

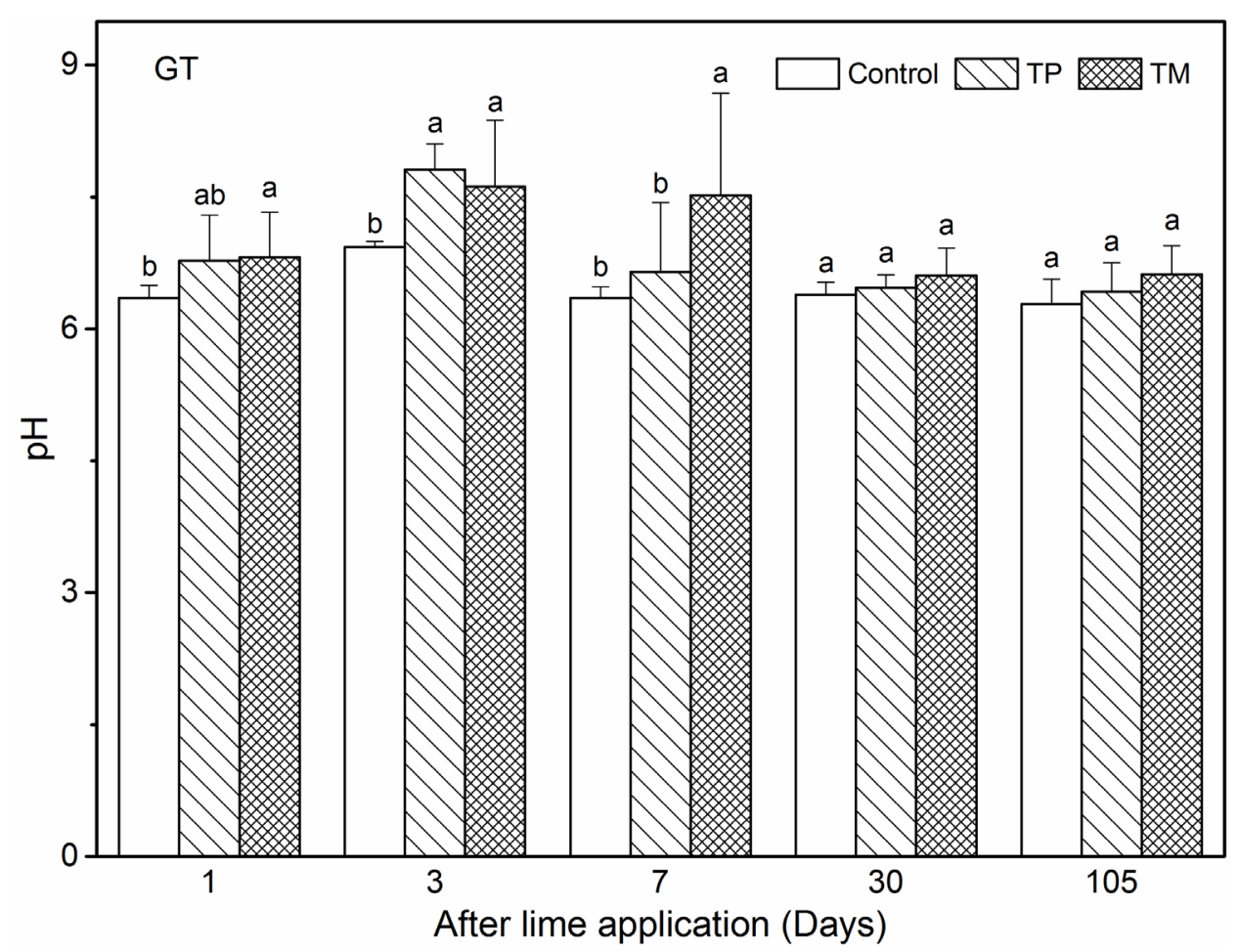

FIGURE 2. Soil pH of paddy field limed with different applying method during the rice growth period at Gaojia town site (GT) (error bars represent the \% standard deviation, $\mathrm{n}=3$; different letter above bars indicate a significant difference at $P<0.05$ from each other at identical sampling day as determined by LSD method). TM, Massive quicklime; TP, Powdered hydrated lime 
$\mathrm{pH}$ by $1.17 \mathrm{pH}$ unit at 7 days after lime application for $\mathrm{TM}$, and by $0.77 \mathrm{pH}$ unit at 3 days lime application for TP was observed, respectively. Thereafter, no significant difference in soil-pH was noted between treatments until the end of experiment.

The subsequent experiments showed an increase in soil $\mathrm{pH}$ with an increase in liming rate. The maximum $\mathrm{pH}$ in liming treatments attained earlier at QT (1 day after lime application) than at HT (7 days) (Figure 3). The application rates of burned lime used from 750 to 3750
$\mathrm{Mg} / \mathrm{ha}$ ( $\mathrm{T} 1$ to $\mathrm{T} 5)$ increased the soil $\mathrm{pH}$ at an average of 0.18 to 1.16 units for HT and 0.12 to 1.38 for QT across the whole experiment compared to control (T0), respectively. However, at the end of experiments, only soil $\mathrm{pH}$ amended with lime rates ranged from $\mathrm{T} 2$ to $\mathrm{T} 5$ at HT and T3 to T5 at QT were significantly higher than control (T0), and these treatments rose soil-pH above 0.5 units compared with that of before experiment simultaneously. These evidences indicate the minimum burned lime rate $(>1500 \mathrm{Mg} / \mathrm{ha})$ to effectively amend the acidic soils.

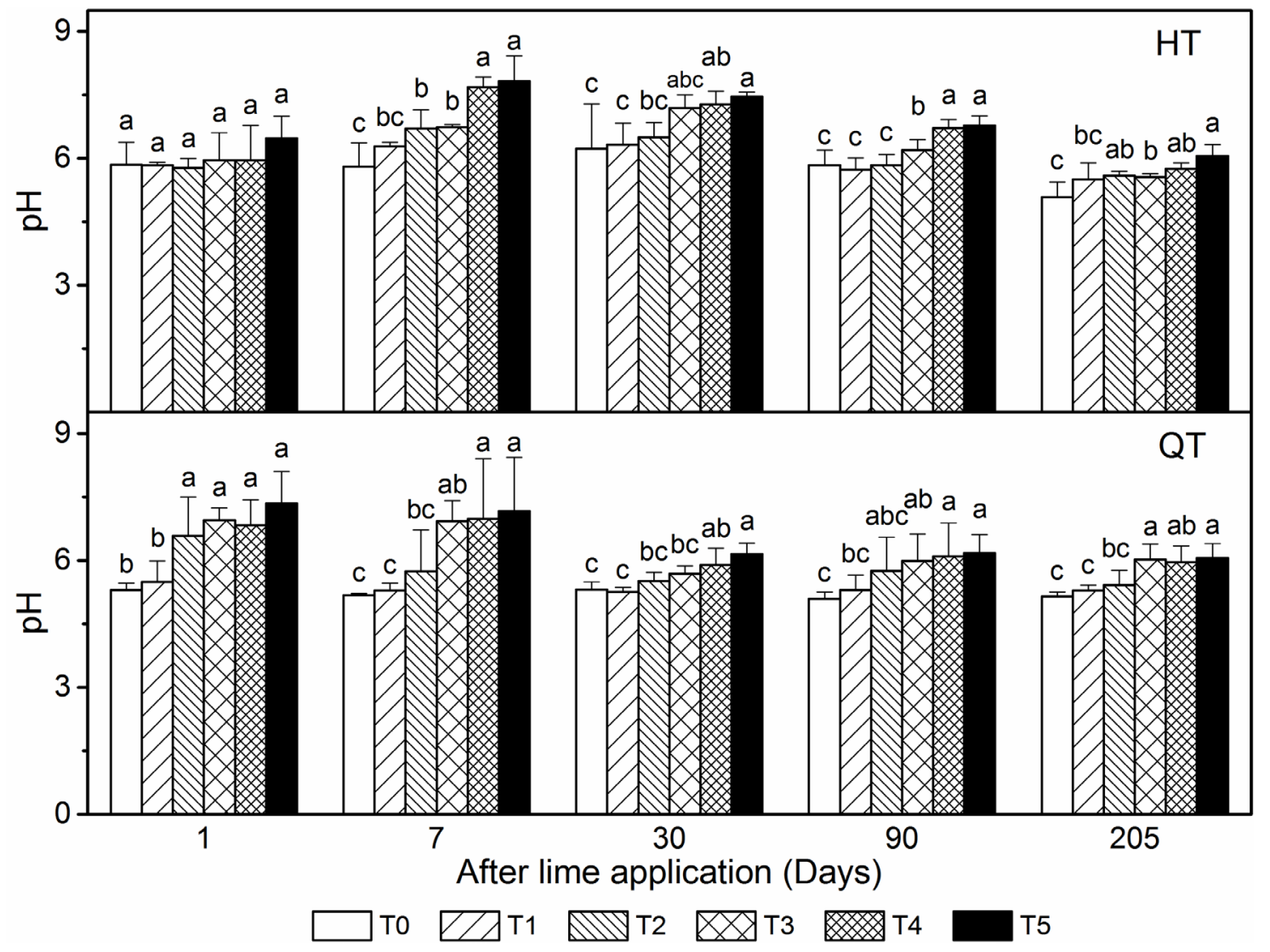

FIGURE 3. Soil $\mathrm{pH}$ of paddy field limed with different rates during periods of double season rice growth at Hecun town site (HT) and Qinghu town site (QT). (error bars represent the \% standard deviation, $\mathrm{n}=3$; different letter above bars indicate a significant difference at $P<0.05$ from each other at identical sampling day as determined by LSD method)

THE DYNAMICS OF SOIL OM, TN AND AVAILABLE-P AFFECTED BY LIME APPLICATION

The organic matter contents, total and available nutrients (OM, TN and Avai-P) of soil treated with various rates of massive burned lime are presented in Figure 4. However, the effect of lime on soil nutrients were differed between
HT and QT. For soil organic matter content, appeared to be a raised tendency with increasing lime rates at HT (Figure 4(a)), especially after 7 days of lime application and at early rice harvesting, where the organic matter content in T5 significantly increased by $22.8,28.7$, and $11.9 \%$ and by $14.1,17.3$, and $15.8 \%$ compared with $\mathrm{T} 0, \mathrm{~T} 1$, and $\mathrm{T} 2$, 
respectively. Afterwards, application of lime showed a slight elevation in OM contents but with no significant difference compared to control soil. In contrary, there was a negative correlation between $\mathrm{OM}$ and lime rate after 30 days of lime application at QT (Figure 4(b)). The OM in T4 and T5 significantly declined by 10.7 and $11.0 \%$ after early rice maturity, and significantly dropped in T3, T4, and $\mathrm{T} 5$ treated plots by $8.8,11.1$, and $9.4 \%$ at late rice maturity compared to $\mathrm{T} 1$, but not significantly change to control. The effect of lime on TN was similar to OM both at HT and QT (Figure 4(c) and 4(d)). At HT, the TN after 7 days of application was significantly increased by 14.0 and $17.9 \%$ with T5 treatment as compared to $\mathrm{T} 0$ and $\mathrm{T} 1$, and by $22.3,33.8$, and $21.8 \%$ compared with T0, T1, and T2 after early rice harvesting, respectively. While at QT, they were not significantly affected by liming throughout two growing seasons, although liming significantly decreased the OM.
Available-P in soil varied over time in either of sites (Figure 4(e) and 4(f)). The highest values were observed at 7 days of rice transplanting as a result of fertilizer application, followed by a gradual decrease to lowest value at end of early rice production. However, Figure 4(e) and 4(f) showed that avai-P was positively affected by liming during early rice period. For HT site, the highest avai-P was obtained immediately after 1 day of lime application in T5, and significantly higher than T1 and T2 at HT, but no difference against T0. After 7 days of lime application, the avai-P showed a rising trend with increased lime rates where $\mathrm{T} 5$ treatment significantly increased by 36.3 and $28.0 \%$ compared with $\mathrm{T} 0$ and $\mathrm{T} 1$. While at QT, the highest avai-P was observed in T4 and the lowest values in T2 after 7 days of lime application. Afterward to the end of experiment, the avai-P in soil was not affected by liming.

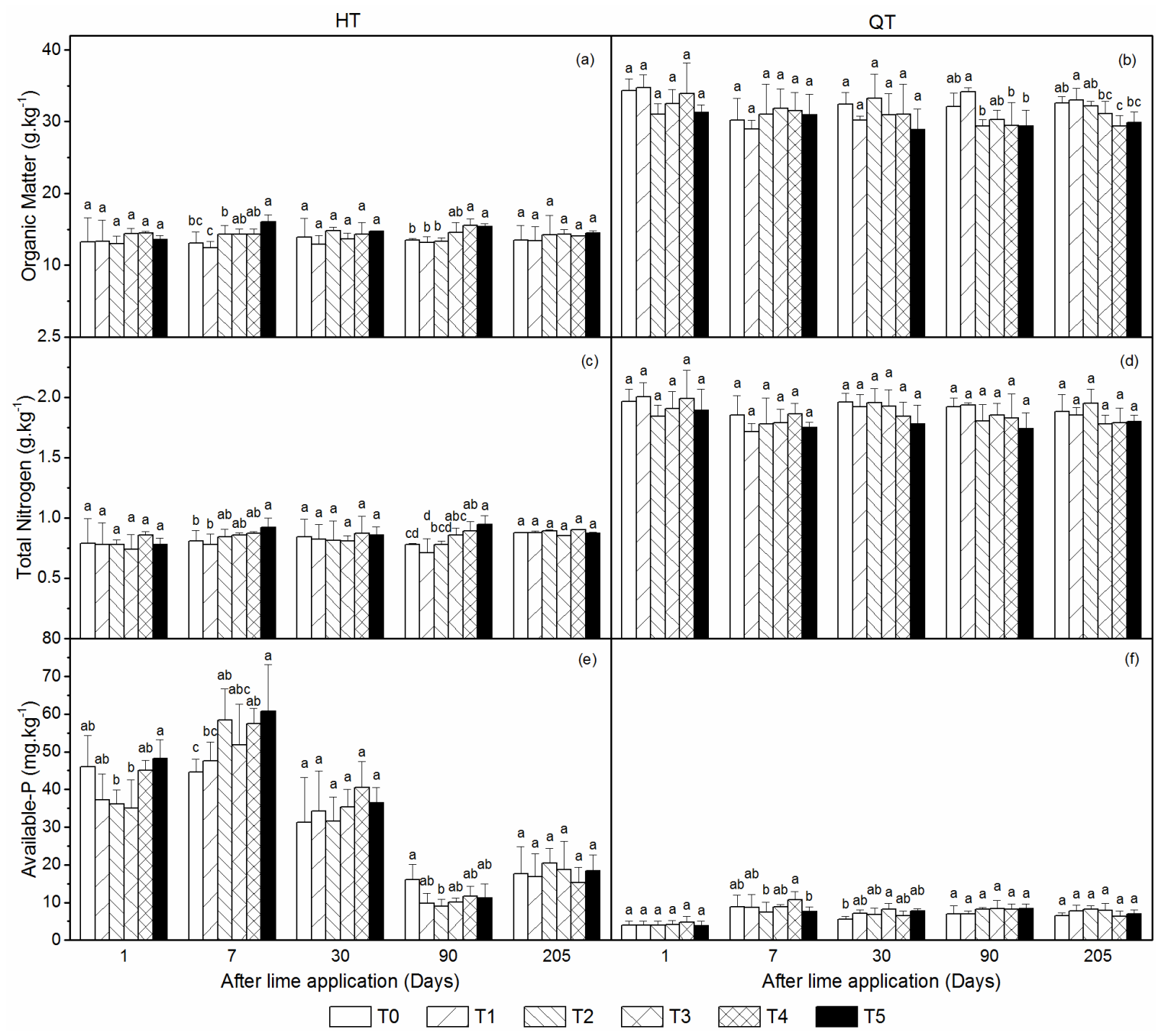

FIGURE 4. Soil nutrients of paddy field limed with different rates during periods of double season rice growth at Hecun town site (HT) and Qinghu town site (QT). (error bars represent the $\%$ standard deviation, $n=3$; different letter above bars indicate a significant difference at $P<0.05$ from each other at identical sampling day as determined by LSD method) 


\section{THE EFFECT OF LIME RATES ON RICE YIELDS}

The difference in rice yield caused by different lime rates was noticed at HT and QT (Table 2). The results showed a gradual increase in grain yield with increasing lime rates, followed by a slow decrease in yield with further rise in lime rates. The highest yield of early rice was observed with lime rate of $750 \mathrm{~kg} / \mathrm{ha}$ at HT although without statistical difference between treatments, while that was in lime rate of $3750 \mathrm{~kg} / \mathrm{ha}$ at QT with significantly higher than lime rate of $750 \mathrm{~kg} / \mathrm{ha}$. As regards with late rice, the maximum yield was obtained in T3 with lime rate of $2250 \mathrm{~kg} / \mathrm{ha}$ at HT and in T4 with lime rate of $3000 \mathrm{~kg} /$ ha at QT, respectively, and both significantly higher than treatments with lime rate below $750 \mathrm{~kg} / \mathrm{ha}$. This indicated that either massive quicklime or powdered hydrated lime was beneficial to rice production when applied in proper rates.

TABLE 2. Rice grain yields of different treatments at two localities $(\mathrm{kg} / \mathrm{ha})$. Numbers in parentheses denote the SD of the mean $(n=3)$

\begin{tabular}{ccccc}
\hline \multirow{2}{*}{$\begin{array}{c}\text { Application rates } \\
(\mathrm{kg} / \mathrm{ha})\end{array}$} & \multicolumn{2}{c}{ HT } & Early rice & Late rice \\
\cline { 2 - 5 } 0 & Early rice & Late rice & $7483.7(744.0)^{\mathrm{ab}}$ & $8676.2(316.3)^{\mathrm{b}}$ \\
\hline 750 & $6714.5(568.2)^{\mathrm{a}}$ & $8559.6(431.6)^{\mathrm{c}}$ & $7261.7(173.4)^{\mathrm{b}}$ & $8690.2(434.9)^{\mathrm{b}}$ \\
1500 & $6776.0(350.6)^{\mathrm{a}}$ & $8673.4(489.9)^{\mathrm{bc}}$ & $7453.6(951.0)^{\mathrm{ab}}$ & $8895.3(343.4)^{\mathrm{ab}}$ \\
2250 & $6616.2(665.4)^{\mathrm{a}}$ & $8842.0(341.1)^{\mathrm{abc}}$ & $7634.6(510.3)^{\mathrm{ab}}$ & $8991.0(530.3)^{\mathrm{ab}}$ \\
3000 & $6226.7(396.6)^{\mathrm{a}}$ & $9274.4(587.3)^{\mathrm{a}}$ & $7663.3(522.4)^{\mathrm{ab}}$ & $9042.0(342.9)^{\mathrm{a}}$ \\
3750 & $6529.0(725.0)^{\mathrm{a}}$ & $9058.6(244.4)^{\mathrm{ab}}$ & & \\
& $6544.8(227.7)^{\mathrm{a}}$ & $8962.0(799.3)^{\mathrm{abc}}$ & $7915.1(692.7)^{\mathrm{a}}$ & $8845.3(666.4)^{\mathrm{ab}}$ \\
\hline
\end{tabular}

The different letters followed by yield means within a column indicate a significant difference $(P<0.05)$ between treatments as determined by LSD method

\section{DISCUSSION}

\section{IMPROVED LIMING TECHNOLOGY AND TRADITIONAL LIMING METHOD}

As an efficient ameliorating practice for agricultural acidic soils, liming has been widely used over the world, and its beneficial effects also have been well established in agricultural production (Arshad et al. 2012; Shamshuddin et al. 2016; Tang et al. 2003). However, many farmers are reluctant to follow these studies particularly due to its unfavorable economic benefits, especially in terms of time and labor, pollution to environment and caused harm to skin of operators as using powder lime material (such as hydrated lime and ground stone lime). In 2016, a farmer lived in QT, Jiangshan City, owned about 100 ha paddy fields was recommended to use massive quicklime instead of traditional hydrated lime for amending acidic soils. It successfully achieved the expected results in about 16 ha of tentatively fields, with high yield of rice without generating flying dusts or corresponding adverse impacts. The study showed that the similar ameliorating effects for soil $\mathrm{pH}$ was obtained by lime application with massive quicklime and hydrated lime, and rice yield also not any difference between these two lime materials (Table 3 \& Figure 2). The similar ameliorating effects for soil $\mathrm{pH}$ with the same applying rates between two lime types maybe the facts that the massive quicklime $(\mathrm{CaO})$ released more $\mathrm{OH}^{+}$ during reaction with water, but contained more impurity compared to hydrated lime $\left(\mathrm{Ca}(\mathrm{OH})_{2}\right)$. Furthermore, compared to hydrated lime, the labor cost of applying massive quicklime investigated from eight local farmers in 2018 were cheaper by $¥ 90$ yuan/ha (Table 3 ). The powdered hydrated lime (TP) raised the soil $\mathrm{pH}$ to peak earlier than do the quicklime due to finer lime material with the neutralization reactions of powdered hydrated lime with soil acidity were more rapidly than did the massive burned lime. This result is consistent with 
previous researches (Álvarez et al. 2010, 2009), they also found the application of finer liming materials increased the soil $\mathrm{pH}$ more rapidly than coarser materials in a magnesium limestone test with different particle size. A slightly increase of $\mathrm{pH}$ observed in TM treatment within 7 days after application may be resulted from incomplete mixing yet as incorporating lime into soil by manually turning over. However, this is not a problem because lime was mixed into soil thoroughly by ploughing with large sized tractor in practical agriculture. These evidences confirmed that the massive quicklime applying into agricultural soil is an impeccable technology with clean, practical, economic and environmentally friendly.

TABLE 3. Comparison between two methods for effect of applying lime. TP, Powdered hydrated lime; TM, Massive quicklime. Numbers in parentheses denote the SD of the mean $(n=3)$

\begin{tabular}{ccccccc}
\hline $\begin{array}{c}\text { Application } \\
\text { methods }\end{array}$ & Shape & $\begin{array}{c}\text { Environmental } \\
\text { pollution }\end{array}$ & $\begin{array}{c}\text { Skin } \\
\text {-damaging }\end{array}$ & $\begin{array}{c}\text { Labour cost } \\
\left(¥ / \mathrm{hm}^{2}\right)\end{array}$ & $\begin{array}{c}\text { Rice yields } \\
\left(\mathrm{kg} / \mathrm{hm}^{2}\right)\end{array}$ & $\begin{array}{c}\text { Results of } \\
\text { reducing acids }\end{array}$ \\
\hline \multirow{2}{*}{$\mathrm{TP}$} & $\begin{array}{c}\text { Powdered hydrated } \\
\text { lime }\end{array}$ & Air pollution & Great & 300 & 7245.0 & Fine \\
& & & & & & \\
Massive quicklime & $\begin{array}{c}\text { Little or no } \\
\text { pollution }\end{array}$ & Little & 210 & 7065.0 & Fine \\
& & & & & $(474.3)^{\mathrm{a}}$ & \\
\hline
\end{tabular}

The different letters followed by yield means within a column indicate a significant difference $(P<0.05)$ between treatments as determined by LSD method

RESPONSE OF SOIL PROPERTIES TO VARIOUS RATES OF LIME

It is widely known that the applying of limes possessed a remarkable effect for acidified soil. After two seasons of rice growing in present tests, the increase rate of soil $\mathrm{pH}$ amended with high lime was clearly higher than the low lime treatments compared to the control. According to Edwards and Beegle (1988), for purposes of normal agronomic soil recommendations, $\mathrm{pH}$ changes less than 0.5 units does usually not consider to be 'practical' $\mathrm{pH}$ changes with respect to soil management practices, sampling and analytical uncertainly. This study showed the quicklime rates of $<1500 \mathrm{Mg} / \mathrm{ha}$ at $\mathrm{HT}$ or $<2250 \mathrm{Mg} /$ ha at QT improved the soil-pH with a value of less than 0.5 unit compared with that of before treatment, indicating these rates of quicklime were insufficient to mitigate soil acidity. Additionally, some differences were noted in $\mathrm{pH}$ changes between two experiment sites. QT soil was slightly more responsive with lime (rising and declining more rapidly) but less change extent than HT soil. These variations reflected different soil type and its properties, with greater sand content and higher OM in QT soil than in HT soil (Table 1). The soil contained high clay content or OM possessed high $\mathrm{pH}$ buffer capacity ( $\mathrm{Li}$ et al. 2018; Wang et al. 2016). The increase of $\mathrm{pH}$ in control soil during the periods of rice growth because the $\mathrm{pH}$ value in submerged paddy soils tends to converge to neutrality irrespective of initial $\mathrm{pH}$ (McBride 1994).
Considering different soil characteristics, the influences of OM, TN and avai-P in two site soils by liming seem toward opposing tendency with an increase for HT soil but slightly decline for QT soil, respectively, especially at the stage of after fertilizing (Figure 4). Paradelo et al. (2015) reviewed numerous previous researches and concluded that increasing or dropping by liming in soil organic matter depended on three factors: The first one is enhancing mineralization via promoting activity of soil biological with $\mathrm{pH}$ rise, and lead to a decline in OM. The second one is reducing decay through increasing the stability of clay assemblages and clay-organic matter bonds, resulting an increase of $\mathrm{OM}$ protection. Finally, a potential increase of $\mathrm{C}$ inputs due to enhancing plant biomass as liming ameliorates soil conditions to plant growth. Compared to unlimed soil, the increase of organic matter by $3.8-12.3 \%$ in HT with rates of applying lime $>1500 \mathrm{~kg} / \mathrm{ha}$, possible high silt-clay soil is advantageous to forming more stable structure and non-favourite to biological activity, which most resisted to degradation of OM (Filho et al. 2018; Mavi et al. 2018).

Whereas, a decrease by $0.4-3.9 \%$ in QT soil maybe as a result of contrary conditions due to high sand soil that accelerated microbial activity and thus decomposition rate in OM (Creamer et al. 2016; Kiem \& Kandeler 1997; Sugihara et al. 2010). Furthermore, the higher organic matter in QT soil maybe is another important factor 
enhancing degradation due to providing substantially adequate $\mathrm{C}$ for biological reproduction (Jiao et al. 2011). Whereas the low OM in HT soil showed that a decrease in SOC mineralization following liming was due to increased microbial C-use efficiency (Grover et al. 2017). Regarding effects of TN affected by lime, there is a similar tendency of changes of organic matter with an increase in HT soil as lime applying rates rise, but a drop in QT soil. The TN drops in QT corresponding to OM can be explained by previous studies. Teutscherova et al. (2016) and Zhuang et al. (2016) suggested that liming can significantly enhance soil nitrification, especially for nitrogen fertilizer (most in the form of ammonium $\left(\mathrm{NH}_{4}^{+}\right)$or $\mathrm{NH}_{4}^{+}$based compounds) which can be rapidly converted into nitrate $\left(\mathrm{NO}_{3}^{-}\right)$via nitrification. This process maybe caused $\mathrm{N}$ losses via $\mathrm{NO}_{3}^{-}$leaching or nitrous oxide $\left(\mathrm{N}_{2} \mathrm{O}\right)$ emissions when cumulative mineralized nitrogen $\left(\mathrm{NH}_{4}^{+}+\mathrm{NO}_{3}^{-}\right)$greatly exceed crops uptake. Additionally, in acidic sandy soil, liming also significantly increased $\mathrm{N}_{2}$ emissions as a result of the significant increase in denitrification (Senbayram et al. 2019).

Phosphorus (P), an essential macro-nutrient for crop growth, its availability in agricultural soils must be assured adequately to avoid being a yield-limiting factor in crop production. In general, most of phosphorus is presented as $\mathrm{Al}$ or Fe oxides, hydroxides, allophane and kaolinite, bounded as calcium-phosphates, or presented in organic forms (Simonsson et al. 2018; Wijanarko \& Taufiq 2016). Its availability is highly pH-dependent, usually decreasing avai-P with increasing $\mathrm{pH}$ due to the formation of less soluble Ca-phosphate, whereas increasing with $\mathrm{pH}$ dropping as result of release of precipitation (Fageria \& Baligar 1999; Wijanarko \& Taufiq 2016). However, the decrease of avai-P in soils with lower $\mathrm{pH}$ might be owed to precipitation as highly insoluble Fe and Al phosphates (Fageria \& Baligar 1999; Park \& Ro 2018), and vice versa, enhancing pH may accelerate the mineralization of organic-P, dissolution of Fe-P and Al-P complexes, thus increasing avai-P (Arshad et al. 2012; Karaivazoglou et al. 2007; Li et al. 2018). Hence, the mechanism of avai-P changes occurred after lime application may depend on the various soil characteristics. Controversy surrounded the effects of liming on avai-P in soils with some previous studies, reporting a negative (Blomquist et al. 2017; Shamshuddin et al. 2016) and others a positive relationship (Arshad et al. 2012; Li et al. 2018; Simonsson et al. 2018). In this study, a similar increase in avai-P due to lime application during most cases of early rice growth, as happened in the previous study, may cause some solubilization of $\mathrm{P}$ from Fe-P and Al-P complexes, as well as release from mineralized organic-P. Largely possible, increasing avai-P is originated from solubilizing in Fe-P or/and Al-P complexes at HT, while from OM degradation at QT, corresponding increase of low OM and drop of high one by liming. Eventually, a noteworthy concern should be considered that fresh water eutrophication caused by losses of excessive soluble nutrients (mainly $\mathrm{N}$ and $\mathrm{P}$ ) (Harun et al. 2021; Teutscherova et al. 2017; Tucher et al. 2018; Zhuang et al. 2016), and deficiency in certain elements when applying quicklime to agricultural soil (Holland et al. 2019; Karaivazoglou et al. 2007).

\section{RESPONSE OF RICE YIELDS TO VARIOUS RATES OF LIME}

An adequate nutrient availability in soils is crucial to crop growth (Bhardwaj et al. 2020; Saha et al. 2019), and the increase in crops yield benefited from lime application due to improving the soil nutrient are well reported by previous researchers. For instance, a 3 years' field experiments conducted by Tang et al. (2003) in Wongan Hills, Western Australia found wheat yield increased by $23-24 \%$ and barley shoot biomass increased by $45-70 \%$ in the limed soils compared with unlimed soils. On an Albright silt loam soil in Canadian, Arshad et al. (2012) noted liming with a calcium carbonate rate of $6.72 \mathrm{Mg} / \mathrm{ha}$ significantly increased grain yields of barley, canola and pea by 38,31 , and $49 \%$, respectively, compared with control. In paddy field, rice grain yield was also significantly enhanced by a maximum of $11.1 \%$ for first rice and $47.1 \%$ for second rice following lime application with different rates (Shamshuddin et al. 2016). The present study showed that applying lime significantly increased the rice yield in strongly acidic paddy field (soil $\mathrm{pH} \approx 5.1$ ) at HT and QT, while no influence in weakly acidic field (soil $\mathrm{pH} \approx 6.0$ ) at GT (Table 2). This result was in agreement with the conclusion studied by Paganiand and Mallarino (2015), they considered that no increase in soybean yield resulted from liming in soil with $\mathrm{pH}>6.5$. Meanwhile, the effect of lime application was higher in late rice than in early rice, i.e. delayed effectiveness may be due to insufficient time for lime application to fully mixing with soil, as reported by previous studies (Blomquist et al. 2017; Edwards \& Beegle 1988; Shamshuddin et al. 2016). However, the liming efficiency in rice yield increase is not as great as reporting by other researchers. The main cause maybe is various crops species with different tolerance to soil acidity and sensitivity to soil $\mathrm{pH}$. Among the most (farmed) crops, rice is the most tolerant to soil acidity with suitable $\mathrm{pH}$ of 6.0 and can grow well even though water $\mathrm{pH}$ is below 5 (Fageria \& 
Baligar 1999; Shamshuddin at al. 2016). Furthermore, three above-mentioned tests all performed on serious acidic soils ( $\mathrm{pH}<5.0)$, where multiple element toxicities such as Al, Mn, Fe (Álvarez et al. 2009; Karaivazoglou et al. 2007; Li et al. 2018) and nutrient deficiencies such as $\mathrm{Ca}, \mathrm{Mg}, \mathrm{N}, \mathrm{P}, \mathrm{B}$, etc (Li et al. 2018; Shamshuddin et al. 2016) most probably occurred. Thus, remarkable and positive impacts are gained easily by eliminating those limiting-factors with lime amending. In this study, the soils maintained $\mathrm{pH}$ of above 5.0 throughout the double season rice cycle, indicating responsible for little increase of late rice yield is more likely to be other factors associated with improving soil porous system (Ferreira et al. 2018), nutrient balances and crop uptake (Bailey 1995; Karaivazoglou et al. 2007; Seth et al. 2018), and biological activity (Alvarez et al. 2010; Kiem \& Kandeler 1997). Additionally, the data obtained from late rice yields demonstrated lime application rates of $>2250 \mathrm{~kg} /$ ha to high clay soils or $>3000 \mathrm{~kg} /$ ha to high sand soils are regarded as a somewhat harmful effect for rice growth in paddy field. However, over-liming of agricultural soils is also known to reduce soil productivity through a variety of complex processes ranging from restricted nutrient availability and to increased element toxicity or disease (Pagani \& Mallarino 2015). Consequently, in practical agriculture production, it is imperative to define correctly lime requirements for optimum soil $\mathrm{pH}$ and further crops growing in acidic soil.

\section{CONCLUSION}

The ameliorating effectiveness of acidic paddy soil by massive quicklime and powered hydrated lime application was compared in the present work. The results showed that similar ameliorating effects on agricultural acidic soil between massive quicklime and powered hydrated lime. The improved method by applying massive quicklime is the most promising method with clean, practical, economic and environmentally friendly approach. Further experiments also showed that the high dosages of massive quicklime application significantly increased soil nutrients, such organic matter, total nitrogen and available phosphorus at Hecun town with a clay loam soil, while appeared to be a decline tendency at Qinghu town with a sandy loam soil. A gradual increase in grain yield with increasing dose of massive quicklime, followed by a slow decrease in yield with further rise in lime rates was observed but with different response at two sites. Conclusively, application of massive quicklime as an economic and environmentally-friendly technique can be more acceptable by farmers to correct acidic soils worldwide. The optimal rates of massive quicklime for rice cultivation on acidic paddy field were 1500-2250 $\mathrm{kg} / \mathrm{ha}$ for clay soil and 2250-3000 kg/ha for sandy soil, respectively.

\section{ACKNOWLEDGEMENTS}

The research was supported by science and technology projects (2018Z2001) in Jiangshan City, Zhejiang province, China. I gratefully acknowledge Jian-fu and Jian-ai family farms for supplying experimental fields, Jiang Xinyou for heavy work in experiment field, and Dr. Yasir Hamid from Zhejiang University for correcting language errors of this manuscript.

\section{REFERENCES}

Álvarez, E., Viadè, A., Fernández-Marcos, M.L. \& HernándezNistal, J. 2010. Limestone particle size and liming scheduling influence soil properties and pasture production. Soil Science 175: 601-613.

Álvarez, E., Viadé, A. \& Fernández-Marcos, M.L. 2009. Effect of liming with different sized limestone on the forms of aluminium in a Galician soil (NW Spain). Geoderma 152(12): $1-8$.

Arshad, M.A., Soon, Y.K., Azooz, R.H., Lupwayi, N.Z. \& Chang, S.X. 2012. Soil and crop response to wood ash and lime application in acidic soils. Agronomy Journal 104(3): 715-721.

Bailey, J.S. 1995. Liming and nitrogen efficiency: Some effects of increased calcium supply and increased soil $\mathrm{pH}$ on nitrogen recovery by perennial ryegrass. Communications in Soil Science and Plant Analysis 26(7-8): 1233-1246.

Bhardwaj, A.K., Rajwar, D., Basak, N., Bhardwaj, N., Chaudhari, S.K., Bhaskar, S. \& Sharma, P.C. 2020. Nitrogen mineralization and availability at critical stages of rice (Oryza sativa) crop, and its relation to soil biological activity and crop productivity under major nutrient management systems. Journal of Soil Science and Plant Nutrition 20: 1238-1248.

Blomquist, J., Simonsson, M., Etana, A. \& Berglund, K. 2017. Structure liming enhances aggregate stability and gives varying crop responses on clayey soils. Acta Agriculturae Scandinavica, Section B - Soil \& Plant Science 68(4): 311322.

Edwards, D.E. \& Beegle, D.B. 1988. No-till liming effects on soil-pH, corn grain yield and earleaf nutrient content. Communications in Soil Science and Plant Analysis 19(5): 543-562.

Fageria, N.K. \& Baligar, V.C. 1999. Growth and nutrient concentrations of common bean, lowland rice, corn, soybean, and wheat at different soil pH on an inceptisol. Journal of Plant Nutrition 22(9): 1495-1507. 
Ferreira, T.R., Pires, L., Wildenschild, D., Heck, R. \& Antonino, A. 2018. X-ray microtomography analysis of lime application effects on soil porous system. Geoderma 324 : 119-130.

Filho, A.C.A.C., Crusciol, C.A.C., Guimarães, T.M., Calonego, J.C. \& Da Costa, C.H.M. 2018. Changes in soil physical properties and carbon protection mechanisms by surface application of lime in a tropical no-tillage system. Soil Science Society of America Journal 82(1): 56-65.

Gatch, E.W. \& du Toit, L.J. 2017. Limestone-mediated suppression of Fusarium wilt in spinach seed crops. Plant Disease 101(1): 81-94.

Grover, S.P., Butterly, C.R., Wang, X. \& Tang, C. 2017. The short-term effects of liming on organic carbon mineralisation in two acidic soils as affected by different rates and application depths of lime. Biology and Fertility of Soils 53(4): 431-443.

Harun, S.N., Hanafiah, M.M., Nizam, N.U.M. \& Rasool, A. 2021. Water and soil physicochemical characteristics of different rice cultivation areas. Applied Ecology and Environmental Research 18(5): 6775-6791.

Holland, J.E., White, P.J., Glendining, M.J., Goulding, K.W.T. \& McGrath, S.P. 2019. Yield responses of arable crops to liming - an evaluation of relationships between yields and soil $\mathrm{pH}$ from a long-term liming experiment. European Journal of Agronomy 105: 176-188.

Jiao, X.G., Gao, C.S., Sui, Y., Zhang, X. \& Ding, G. 2011. Research on soil microbial ecology under diferent soil organic matter levels in farmland. Scientia Agricultura Sinica 44: 3759-3767.

Karaivazoglou, N.A., Tsotsolis, N.C. \& Tsadilas, C.D. 2007. Influence of liming and form of nitrogen fertilizer on nutrient uptake, growth, yield, and quality of Virginia (flue-cured) tobacco. Field Crops Research 100(1): 52-60.

Kiem, R. \& Kandeler, E. 1997. Stabilization of aggregates by the microbial biomass as affected by soil texture and type. Applied Soil Ecology 5(3): 221-230.

Kunito, T., Isomura, I., Sumi, H., Park, H.D., Toda, H., Otsuka, S., Nagaoka, K., Saeki, K. \& Senoo, K. 2016. Aluminum and acidity suppress microbial activity and biomass in acidic forest soils. Soil Biology and Biochemistry 97: 23-30.

Li, Y., Cui, S., Chang, S.X. \& Zhang, Q. 2018. Liming effects on soil $\mathrm{pH}$ and crop yield depend on lime material type, application method and rate, and crop species: A global metaanalysis. Journal of Soils and Sediments 19: 1393-1406.

Mavi, M.S., Singh, G., Singh, B.P., Singh Sekhon, B., Choudhary, O.P., Sagi, S. \& Berry, R. 2018. Interactive effects of riceresidue biochar and $\mathrm{N}$-fertilizer on soil functions and crop biomass in contrasting soils. Journal of Soil Science and Plant Nutrition 18(1): 41-59.

McBride, M.B. 1994. Environmental Chemistry of Soils. New York: Oxford University Press.

Pagani, A. \& Mallarino, A.P. 2015. On-farm evaluation of corn and soybean grain yield and soil $\mathrm{pH}$ responses to liming. Agronomy Journal 107(1): 71-82.
Paradelo, R., Virto, I. \& Chenu, C. 2015. Net effect of liming on soil organic carbon stocks, A review. Agriculture, Ecosystems and Environment 202: 98-107.

Park, J.S. \& Ro, H.M. 2018. Early-stage changes in chemical phosphorus speciation induced by liming deforested soils. Journal of Soil Science and Plant Nutrition 18(2): 435-447.

Saha, S., Saha, B., Seth, T., Dasgupta, S., Ray, M., Pal, B., Pati, S., Mukhopadhyay, S.K. \& Hazra, G. 2019. Micronutrients availability in soil-plant system in response to long-term integrated nutrient management under rice-wheat cropping system. Journal of Soil Science and Plant Nutrition 19(4): 712-724.

Seth, A., Sarkar, D., Masto, R.E., Batabyal, K., Saha, S., Murmu, S., Das, R., Padhan, D. \& Mandal, B. 2018. Critical limits of Mehlich 3 extractable phosphorous, potassium, sulfur, boron and zinc in soils for nutrition of rice (Oryza sativa L.). Journal of Soil Science and Plant Nutrition 18(2): 512-523.

Senbayram, M., Budai, A., Bol, R., Chadwick, D., Marton, L., Gündogan, R. \& Wu, D. 2019. Soil $\mathrm{NO}_{3}{ }^{-}$level and $\mathrm{O}_{2}$ availability are key factors in controlling $\mathrm{N}_{2} \mathrm{O}$ reduction to $\mathrm{N}_{2}$ following long-term liming of an acidic sandy soil. Soil Biology and Biochemistry 132: 165-173.

Shamshuddin, J., Panhwar, Q.A., Shazana, M.A.R.S., Elisa, A.A., Fauziah, C.I. \& Naher, U.A. 2016. Improving the productivity of acid sulfate soils for rice cultivation using limestone, basalt, organic fertilizer and or their combinations. Sains Malaysiana 45(3): 383-392.

Simonsson, M., Östlund, A., Renfjäll, L., Sigtryggsson, C., Börjesson, G. \& Kätterer, T. 2018. Pools and solubility of soil phosphorus as affected by liming in long-term agricultural field experiments. Geoderma 315: 208-219.

Sugihara, S., Funakawa, S., Kilasara, M. \& Kosaki, T. 2010. Effect of land management and soil texture on seasonal variations in soil microbial biomass in dry tropical agroecosystems in Tanzania. Applied Soil Ecology 44(1): 80-88.

Tang, C., Rengel, Z., Diatloff, E. \& Gazey, C. 2003. Responses of wheat and barley to liming on a sandy soil with subsoil acidity. Field Crops Research 80(3): 235-244.

Teutscherova, N., Vazquez, E., Masaguer, A., Navas, M., Scow, K.M., Schmidt, R. \& Benito, M. 2017. Comparison of lime- and biochar-mediated $\mathrm{pH}$ changes in nitrification and ammonia oxidizers in degraded acid soil. Biology and Fertility of Soils 53(7): 811-821.

Tucher, S.V., Hörndl, D. \& Schmidhalter, U. 2018. Interaction of soil $\mathrm{pH}$ and phosphorus efficacy: Long-term effects of $\mathrm{P}$ fertilizer and lime applications on wheat, barley, and sugar beet. Journal of the Human Environment 47(Suppl 1): S41-S49.

Wang, X., Tang, C., Baldock, J.A., Butterly, C.R. \& Gazey, C. 2016. Long-term effect of lime application on the chemical composition of soil organic carbon in acid soils varying in texture and liming history. Biology and Fertility of Soils 52: 295-306.

Wijanarko, A. \& Taufiq, A. 2016. Effect of lime application on soil properties and soybean yield on tidal land. Journal of Agricultural Science 38(1): 14-23. 
Zhuang, S., Li, Q., Lv, P. \& Gui, R. 2016. Effect of liming on soil nitrogen loss in runoff from a cultivated bamboo stand. Journal of Soil and Water Conservation 71(4): 356-363.

The Agricultural Technique Popularization Centre of Jiangshan City

Jiangshan, Zhejiang, 324100

China
*Corresponding author; email: man 0034@163.com

Received: 16 January 2021

Accepted: 23 May 2021 